\title{
Soil Fertility under Different Farmland Management Practices for Sustainable Crop Production in Southern Kaduna, Nigeria
}

E. O. Oriola ${ }^{1}$, and B. R. Atiyong ${ }^{2}$

\begin{abstract}
${ }^{1}$ Department of Geography and Environmental Management: Faculty of Social Science, University of Ilorin, Nigeria.
\end{abstract}

2Department of Geography: Faculty of Science, Kaduna State University, Kaduna, Nigeria

Correspondence:

1 lolaoriola@gmail.com

ORCID: $\underline{0000-0003-4353-2480}$

\begin{abstract}
This study assessed the fertility status of the soils under different Farm Management Practices (FMPs) in southern Kaduna, Nigeria. A total of 25 composite soil samples were collected at $0-20 \mathrm{~cm}$ soil depth from three locations under the different FMPs in Katugal, Madakiya, Kurmin Sara, Mailafiya and Zankam. The soil samples were analysed using standard laboratory procedures. Simple proportion and percentages were adopted in analysing and summarizing the data. The study revealed that, $56 \%$ and $44 \%$ of the soils belongs to sandy loam and loam textural classes respectively. These soil textural classes are considered good for the cultivation of maize, guinea corn, millet and ginger in this area. More than $80 \%$ of the soil's bulk densities are within $1.0-1.30 \mathrm{gcm}^{-3}$ threshold, available water holding capacity fell in $0-50 \mathrm{~mm} / \mathrm{m}$. Similarly, electrical conductivity is $>1.0 \mathrm{ds} / \mathrm{m}$, while total nitrogen content in $76 \%$ fell in $0.10-0.20 \mathrm{~kg} / \mathrm{ha}$, threshold value. More than $80 \%$ of the $\mathrm{pH}$ falls within 5.0 and 6.8 in the area. The micronutrients contents are within normal threshold values except zinc and manganese in two of the FMPs. Both microbial biomass nitrogen and soil basal respiration are within the fertility threshold range $>1.10 \%$ and $>2.0 \%$ which are considered normal for plant growth. $72 \%$ of the organic matter content is $<2.6 \%$, while cation exchange capacity of $<12.0 \mathrm{cmol} / \mathrm{kg}$, phosphorus $<8 \mathrm{mg} \mathrm{kg}^{-1}$ and microbial biomass carbon $(0-10 \%)$ in the soils were outside the normal fertility threshold range. The study recommended the use of animal dung, compost, inorganic fertilizers, crop residue as soil conditioners, and liming to improve $\mathrm{pH}$ condition to enhance and sustain the fertility of the soils.
\end{abstract} Key words: Farmland, Farm Practices, Fertility, Soil, Sustainability, Threshold 


\section{Introduction}

Land has been a fundamental resource for human livelihood since time immemorial, more importantly, agricultural land. Unfortunately, this has become scarce due to increasing demand by the ever-increasing population. Therefore, increasing and sustaining agricultural productivity has become a significant challenge among developing nations. Furthermore, Ersado et al. (2003), stated that for most Sub-Saharan African Countries, embracing more effective and productive farming practices and machineries that increase agricultural yield and improve environmental sustainability remains the best option for attaining economic development, food security, and poverty reduction. Effective farmland management practices and proper farming machinery should be put in place to improve soil nutrient status of farmlands for maximum crop production on a sustainable base which will, in turn, raise farmers' proceeds. Thus, farmland management practices as described by Terr Africa Partnership (TAP 2006) are land use methods that enable farmland users to maximize the economic and social benefits from farmland, while sustaining the environmental support functions of the land resources. Consequently, the intensive use of land resources should not only be for what the farmers stand to benefit but should be a concern with the sustenance of the fertility status of soils of agricultural lands.

Intensive use of land for agricultural purposes by farmers have been observed by Geissen et al. (2009), as causing significant changes in soil physical, chemical and biological characteristics that can affect soil fertility, increase soil erosion and soil compaction. In addition, poor understanding of the soil characteristics and insufficient checking of the soil quality under different farmland management practices often encourage depreciation of the agricultural lands and sustainable agricultural practices. However, Lal (2015) stressed that sitespecific practices of restoring soil quality and improve crop yield should include among others, conservation agriculture, integrated nutrient management strategies, continuous vegetative cover with residue mulch, planting of cover crops and controlling grazing of animals at appropriate carrying capacity. The benefits of the site-specific practices of restoring soil quality and improve crop yield are enormous, these include; minimal soil disturbance, permanent soil cover, soil structural stability and nutrient use efficiency, increasing crop water use efficiency and soil organic matter levels and organic carbon pool, boost nitrogen availability, better weed control and improve soil fertility leading to improved crop yields (Shaver et al. 2002; 
Liu et al. 2006; Woodfine 2009; Menale et al. 2009).

Wolf (1995) cited in Ezekiel et al. (2012) observed that irrigation has made higher, and more consistent yield possible as crops can be planted more than once in a year within the tropics. Invariably, according to Oriola (2009), the prospect of irrigation agriculture in transforming the dream of attaining the Millennium Development Goals to reality in Nigeria is high. These benefits cannot be fully achieved without continuous soil monitoring and management of agricultural lands to establish their soil fertility status. Southern Kaduna region like any other region in Nigeria, is a farming community and has benefitted from the adoption of different farming practices over the years without prior knowledge of the inherent soil quality of the agricultural lands. Thus, there is the need to monitor the fertility status of the soil in this area for maximum benefit and continuous sustenance of the soil quality of this region.

Traditionally, farmland in Southern Kaduna is often cleared for planting, and after a short period of cultivation lasting three to five years, the farmland is allowed to rest and recuperate naturally. Between 1970 and 2017 there has been an increase in the population of Southern Kaduna without a commensurate increase in farmland. Furthermore, long fallow periods are no longer practicable, and the cultivation- fallow cycles have become shorter, and in some communities, fallowing as a practice has completely disappeared. Now, indiscriminate seasonal burning of the bush, improper application of inorganic fertilizer, intensive conventional tillage, and continuous monocropping are common practices in Southern Kaduna with no evidence of monitoring of the soil fertility status of agricultural lands. The end results of these unwholesome practices are the deterioration of soil properties and fertility depletion, which, according to Yakubu (2010), resulting in low crop yield. It is also worthy of note that Southern Kaduna is endowed with natural resources; a conducive climate, vast agricultural and grazing lands, perennial rivers and streams, fertile alluvial plains, tourist attraction sites, and a luxuriant vegetation cover. People are attracted to this region because of these vast natural resources coupled with the accommodating and friendly nature of the people. However, agricultural production is affected by the inappropriate and unsustainable use of these resources resulting from soiling fertility depletion and resultant low crop yield leading to food insecurity. To this end, it is not out of place to take a look at the fertility status of soils of farmlands in Southern Kaduna, as this will give an insight to the dwindling fortune of the inherent soil quality for the effective growth of 
crops such as maize, guinea corn, millet, and ginger among others.

The objective of the study was to assess the fertility status of soils under different farmland management practices in Southern Kaduna to ascertain the present quality of the soils of the region. This is with a view to establishing soil fertility status with respect to the threshold limit for the sustenance of maize, guinea corn, millet and ginger in the study area.

\section{Study Area}

Southern Kaduna lies within the Guinea Savanna Agro-ecological Zone of Nigeria, covering approximately 24,536km 2 and lies between latitudes $9^{\circ} 00^{\prime} 00^{\prime \prime}$ and $10^{\circ} \quad 45^{\prime}$ $00^{\prime \prime}$ North of the Equator and longitudes $7^{\circ} 10^{\prime}$ $00^{\prime \prime}$ and $8^{\circ} 45^{\prime} 00^{\prime \prime}$ East of the Greenwich Meridian. The area shares boundaries with Niger State in the West, Federal Capital Territory (FCT) and Plateau State to the South and South-East. It also shares borders with Bauchi States to the East and Kano to the North (Figure 1). The area is designated as Koppen's Aw climate with two distinct seasons, a wet season in summer and a dry season in winter. Rainfall occurs between the months of April to October, while the dry season extends from ending of October of one calendar year to April of the next (Abaje et al. 2015). The mean (Uema'a LGA) and Kurmin Sara (KachiaL GA) annual rainfall is about $1733 \mathrm{~mm}$ in Kafanchan-Kagoro areas in the South of the study area (Abaje et al. 2010), due to the influence of the Jos Plateau with its orographic rainfall to about $1203 \mathrm{~mm}$ in the central part of Kaduna. The mean monthly temperature is $28^{\circ} \mathrm{C}$, while the mean atmospheric relative humidity is about 63\% (Abaje et al. 2015). The vegetation of the area is the Guinea Savanna type. The main type of soil is the Ferruginous tropical soil which is related to the climate, vegetation, lithology and the topography of the area (Abaje et al. 2010). Other soils include the Alfisols, Inceptisols, Vertisols and Cambisols. The soils are well-drained and shallow, with texture consisting of loamy sand to sandy loam topsoils $(0-20 \mathrm{~cm})$ and supports a wide variety of annual, perennial and tree crops, respectively (Eroarome 2009). The relief is relatively flat and undulating, and it influences the drainage pattern of the area (Abaje et al., 2009).

\section{Materials and Methods}

Global Positioning System (GPS) was used for accurate location of the soil sampling points and subsequent collection of the soil samples. Soil samples were taken from five plots of different farmland management practices in five selected settlements notably Katugal (Kagarko LGA), Madakiya (Zango Kataf LGA), Zankam (Kaura LGA), Mailafiya 


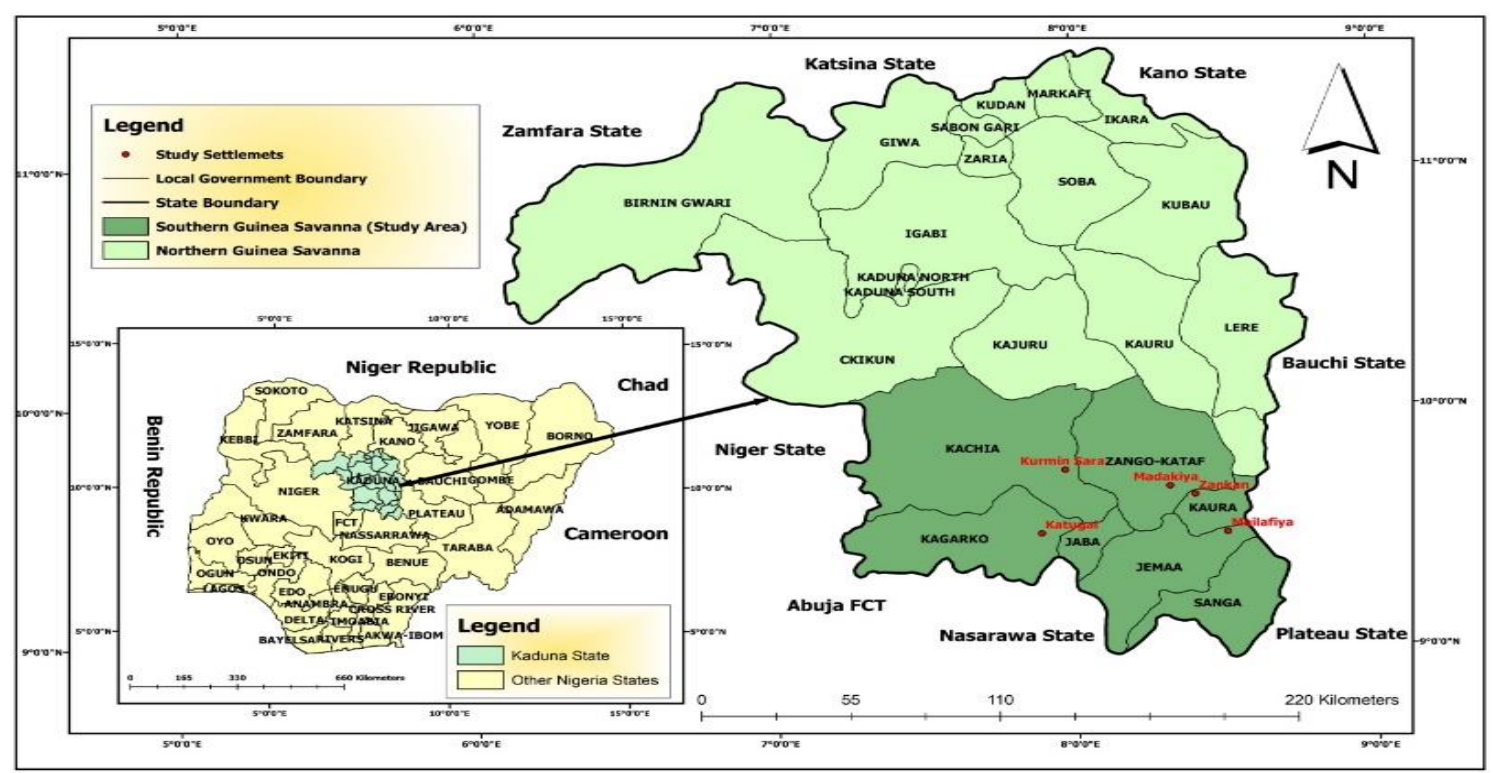

Figure 1: Geographical location of Kaduna state

Source: Ministry of Land and Survey Kaduna, (2017).

These settlements were purposively selected because they have not been displaced by communal or herders/farmers crisis. Johnson and Christensen (2004) argued that purposive sampling relies on the decision of the researcher, based on some well-known criteria which in this case are similarities in terrain, soil and in their farming activities aside from their location stability. The categories of the farmland management practices include intermittent short fallow, minimum tillage /mulching, organic farming, mixed cropping and surface irrigation practice and crops identified based on their cultivation history to include maize, millet, guinea corn, ginger and yam.
Each farmland management practice was demarcated into grids of a one-hectare cell (quadrat) measuring $100 \mathrm{~m}$ by $100 \mathrm{~m}$. Samples were taken at $0-20 \mathrm{~cm}$ soil depth as recommended by Richard et al. (1999), to be the ploughing depth in most agricultural soils, including the majority of root biomass. The samples were taken from three locations (upper, middle, and lower) in a stratified systematic unaligned grid sampling approach using GPS for accurate location of sample points on each hectare to produce a composite soil sample at each management practice to make a total of 25 samples. The soil samples were collected concurrently in all the study sites toward the end of the rainy season precisely in October. The soil samples 
collected were taken to the soil laboratory of the Institute for Agricultural Research (IAR) Ahmadu Bello University Zaria (ABU Nigeria, for analyses of the soil samples to generate the soil data for the study. The soil analysis focuses on the physical, chemical and microbiological parameters that are key to soil fertility and crop yield (maize, millet, guinea corn and ginger).

Each soil sample was air-dried, crushed and sieved through a $2 \mathrm{~mm}$ sieve and used for the assessment of selected soil physico-chemical and biological properties. Soil bulk density was determined by the undisturbed core sampling method after drying the soil samples in an oven at $105^{\circ} \mathrm{C}$ to constant weights (Blake and Hartge 1986). Soil particle size distribution was determined by the Bouycouos hydrometric method (Bouyoucos 1962), after removing organic matter using hydrogen peroxide $\left(\mathrm{H}_{2} \mathrm{O}_{2}\right)$ and dispersing the soils with sodium hexametaphosphate $\left(\mathrm{NaPO}_{3}\right)_{6}$ solution. In order to determine the available water holding capacity (AWHC) of the soil, the field capacity (FC) and permanent wilting point (PWP) was measured at $-1 / 3$ and -15 bars soil water potential, respectively, using the pressure plate apparatus (Klute 1965).

The $\mathrm{pH}$ of the soils was measured in water and calcium chloride $\left(0.01 \mathrm{M} \mathrm{CaCl}_{2}\right)$ suspension in a 1:2.5 (soil: liquid ratio) potentiometrically using a glass-calomel combination electrode (Van Reeuwijk 2002). Exchangeable acidity was determined after extracting with $1 \mathrm{~N} \mathrm{KCl}$ and titrating with $\mathrm{NaOH}$. Organic matter was obtained by multiplying percent soil Organic Carbon by a factor of 1.724 following the assumptions that Organic matter is composed of $58 \%$ carbon. Nitrogen was obtained by the semi-micro kjeidahl Digestion and Distillation method (Bremner and Mulvaney 1982). Cation exchange capacities were thereafter estimated titrometrically by distillation of ammonium that was displaced by sodium from $\mathrm{NaCl}$ solution (Chapman 1965). Phosphorus was analyzed according to the procedure of Olsen et al. (1954) extraction method._Micronutrients were extracted with Diethylenetriaminepentaacetic acid (DTPA) (Lindsay and Norvell 1978) and measured by atomic absorption and emission spectrophotometry. Microbial biomass C \& N was determined by Chloroform Fumigation and extraction procedure (MBC, MBN) (Vance et al. 1987). Similarly, soil basal respiration (RESP) was measured using a multiple sensor respirometer (Micro-Oxymax, Columbus, OH, USA).

Statistical Analyses: The nature of the data collected in line with the objective of the study require simple Descriptive statistics. Therefore, simple proportion and_percentages were used to present and summarise the data 
of all the soil properties from different farmland management practices. Threshold values for rating of soil fertility indicators is reported by Havlin et al (1999); USDA-NRCSC (2011); Smith and Doran (1996) and FMANR (1990) were adopted for establishing the soil fertility status.

\section{Results and Discussion}

\section{Physical-chemical and biological properties}

The results of the soil physical properties distribution for the various farmland management practices under consideration is presented in Table 1 . Not less than $60 \%$ of the soils in the entire study area belong to two textural class, namely sandy loam and loam. It is only the soils under minimal tillage/mulching that have the fair share of the four classes identified in the study area at ratio $4: 2: 2: 2$. Furthermore, it is only in the minimum tillage/mulching that clay loam soil is available. It is non-existence in the other four management practices. These soil textures were considered good for the cultivation of maize, millet, guinea corn and ginger because the percentage of sand separate is high in most of the soil samples of the study farmlands. This is an indication that all the soils of the study area can retain and store moisture for plant use and also allows for adequate aerations of the soils. Oertli (2008), stressed that there is the tendency for the productivity of soil to be better on medium-textured soils consisting of a mixture of sand, silt, and clay than on soils that are light, heavy or mainly silty.

The bulk density of the soil shows that $80 \%$ $100 \%$ of the farmlands surveyed under the five management practices had moderate bulk density within the range of 1.25 and 1.55 $\mathrm{g} / \mathrm{cm} 3$. Irrigation practice was within $0-50$ $\mathrm{mm} / \mathrm{m}$, class 1 soil; hence they belong to a textural. The result of the bulk densities of the entire areas was within the specified standard range of 1.0-3.0 g/cm3, according to Havlin et al. (1999). This is also an indication that the soils in the study areas are capable of retaining moisture for a giving period of time.

Similarly, The available water holding capacity shows all the farmlands under intermittent short fallow, minimum tillage/mulching, mixed cropping, organic farming and surface group of sand to loamy sand. By implication, the fine texture soils of sandy to loamy sand soils under the farmland management practices surveyed has the capacity to hold and retain more moisture. This can facilitate and enhances soil fertility which is good for crop yield sustenance.

The results of the chemical properties are presented in Table 2. The distribution of $\mathrm{pH}$ values show that all the farmlands surveyed under the different farmland management practices were slightly acidic with a $\mathrm{pH}$ range 
of 5.4-6.4, except in surface irrigation and organic farming practices where $40 \%$ and $20 \%$ respectively were below the normal threshold $(<5.0)$. Most plants can tolerate and grow better without liming the soils. In general, most plants are best suited to a $\mathrm{pH}$ of 5.5 on organic soils and pH of 6.5 on mineral soils. The $\mathrm{pH}$ values within 5.0-6.80 are considered ideal for most cultivated crops reported by United State Department of Agriculture (USDA) Natural Resources Conservation Service Center (NRSC) (USDANRCSC 2011) and Brady and Weil (2002). Maize, guinea corn and millet grow best in soil $\mathrm{pH}$ between 5.8 and 6.8. The optimum soil pH for growth of ginger is between 6.0 and 6.5 .

Table 1: Summary of the Ratings of Key Soil Physical Fertility Indicators Compared with their Critical Limits (Threshold Values)

\begin{tabular}{|c|c|c|c|c|c|c|c|}
\hline \multirow[t]{2}{*}{ Indicators } & \multirow{2}{*}{$\begin{array}{l}\text { Threshold } \\
\text { Value * }\end{array}$} & \multirow[t]{2}{*}{ Rating } & \multicolumn{4}{|c|}{ Soil Field Percentages } & \multirow[b]{2}{*}{$\begin{array}{l}\text { Surface } \\
\text { Irrigation }\end{array}$} \\
\hline & & & \multicolumn{2}{|c|}{$\begin{array}{l}\text { Intermittent Minimum } \\
\text { Short fallow Till/Mulch }\end{array}$} & $\begin{array}{l}\text { Mixed } \\
\text { cropping }\end{array}$ & $\begin{array}{l}\text { Organic } \\
\text { Farming } \\
\end{array}$ & \\
\hline \multirow[t]{4}{*}{ Texture } & Sandy loam & & 20.0 & 40.0 & 60.0 & 80.0 & 40.0 \\
\hline & Loam & & 60.0 & 20.0 & 40.0 & 20.0 & 60.0 \\
\hline & Clay loam & & 0.0 & 20.0 & 0.0 & 0.0 & 0.0 \\
\hline & Sandy clay loam & & 20.0 & 20.0 & 0.0 & 0.0 & 0.0 \\
\hline \multirow[t]{3}{*}{ Bulk density } & $<1.0 \mathrm{gcm}^{-3}$ & Loose (low) & 0.0 & 0.0 & 0.0 & 0.0 & 0.0 \\
\hline & $1.0-1.30 \mathrm{gcm}^{-3}$ & Medium & 80.0 & 100.0 & 80.0 & 100.0 & 100.0 \\
\hline & $>1.30 \mathrm{gcm}^{-3}$ & $\begin{array}{l}\text { Dense } \\
\text { (high) }\end{array}$ & 20.0 & 0.0 & 20.0 & 0.0 & 0.0 \\
\hline \multirow[t]{2}{*}{ AWHC } & $\begin{array}{l}0-50 \mathrm{~mm} / \mathrm{m} \\
\text { Class } 1 \text { soils }\end{array}$ & $\begin{array}{l}\text { Sand to } \\
\text { loamy Sand }\end{array}$ & 100.0 & 100.0 & 100.0 & 100.0 & 100.0 \\
\hline & $\begin{array}{l}51-100 \mathrm{~mm} / \mathrm{m} \\
\text { Class } 2 \text { soils }\end{array}$ & Sandy loam & 0.0 & 0.0 & 0.0 & 0.0 & 0.0 \\
\hline
\end{tabular}

Source: Computed from Field Survey Data, 2017, *Source of Threshold Values: Havlin et al. (1999); FMANR (1990)

Furthermore, the result of the Electrical Conductivity shows that all the farmlands surveyed in the study area are saline because the EC is greater than $1.0 \mathrm{ds} / \mathrm{cm}$. The EC values should be in the acceptable range $0.0-0.0$ $0.015 \mathrm{ds} / \mathrm{m}$ ) for "general plant growth and microbial activity" (Smith and Doran 1996), and as a general guideline, an EC level between $0.02-0.12 \mathrm{ds} / \mathrm{m}$ is a good range for growing crops, any record greater than $0.02 \mathrm{ds} / \mathrm{m}$ ) would indicate low nutrient levels and low microbial activity. The result of the content of total nitrogen in the soil shows that not less than $80 \%$ of all the land management practices studied have moderate and high nitrogen content. In contrast, $20 \%$ of the soils in intermittent short fallow, organic farming and surface irrigation practice have low nitrogen content.

These results are similar to the result of the study of Holland et al. (1989) cited in Essoka 
and Essoka (2014), on land evaluation and agriculture in Calabar, where total nitrogen was within the range of $0.04-0.18 \%$, which they rated as high. Likewise, Defoer et al. (2000), in their study on managing soil fertility in the Tropics cited in Essoka and Essoka (2014), considered the soil to be very good since nitrogen value higher than $0.1 \%$ is rated good.

The organic matter contents in the soils of farmlands show $72 \%$ of the soils under the five farmland management practices are moderately fertile (1.7-2.6\%) and quiet ideal for plant growth and sustenance. In contrast, to only $28 \%$ of the farmlands under the management practices that have low organic matter content. Kay and Angers (1999), elucidate that if soil organic carbon levels are less than $1 \%$, it would be challenging to attain maximum agricultural yields, regardless of the soil type.
The cation exchange capacity (CEC) is an expression of soil negative charge. It is desirable that soils of agricultural lands should have a high cation exchange capacity, since it represents soil capacity to retain the elements necessary for plants growths (RangelPeraza et al. 2017), and it also indicates the soil potential to make available calcium, magnesium and potassium to plants. In this regard, the content of CEC shows that all the soils surveyed under the five farmland management practices have low CEC less than $25.0 \mathrm{cmol} / \mathrm{kg}$. This is considered unfavourable and deficient for plant growth. A high cation exchange capacity, with an average value of $36.34 \mathrm{cmol} / \mathrm{kg}$, according to Rangel-Peraza et al. (2017), is considered as soil with great natural fertility. 
Table 2: Summary of the Ratings of Key Soil chemical Fertility Indicators Compared with their Critical Limits (Threshold Values)

\begin{tabular}{|c|c|c|c|c|c|c|c|}
\hline \multirow[t]{2}{*}{ Indicators } & \multirow[t]{2}{*}{ Threshold Value * } & \multirow[t]{2}{*}{ Rating } & \multicolumn{4}{|c|}{ Soil Field Percentages } & \multirow[b]{2}{*}{$\begin{array}{l}\text { Surface } \\
\text { Irrigation }\end{array}$} \\
\hline & & & $\begin{array}{l}\text { Intermittent } \\
\text { Short Fallow }\end{array}$ & $\begin{array}{l}\text { Minimum } \\
\text { Till/Mulch } \\
\end{array}$ & $\begin{array}{l}\text { Mixed } \\
\text { Cropping }\end{array}$ & $\begin{array}{l}\text { Organic } \\
\text { Farming }\end{array}$ & \\
\hline \multirow[t]{3}{*}{$\mathrm{pH} \mathrm{H}_{2} \mathrm{O}_{2}$} & $<5.5$ & Low & 00 & 00 & 00 & $\underline{40.0}$ & $\underline{20.0}$ \\
\hline & $\underline{5.5}$ to 6.8 & Normal & $\underline{100.0}$ & $\underline{100.0}$ & $\underline{100.0}$ & $\underline{60.0}$ & $\overline{80.0}$ \\
\hline & $>6.8$ & Excess & 0.0 & 0.0 & 0.0 & 0.0 & 0.0 \\
\hline \multirow[t]{2}{*}{$\mathrm{EC} \mathrm{ds} / \mathrm{cm}$} & $\leq 1.0 \mathrm{ds} / \mathrm{cm}$ & Normal & $\underline{100.0}$ & $\underline{100.0}$ & $\underline{100.0}$ & $\underline{100.0}$ & $\underline{100.0}$ \\
\hline & $>1.0 \mathrm{ds} / \mathrm{cm}$ & $\overline{\text { Saline }}$ & $\overline{0.0}$ & $\overline{0.0}$ & $\overline{0.0}$ & $\overline{0.0}$ & 0.0 \\
\hline \multirow[t]{3}{*}{ Total Nitrogen $(\mathrm{kg} / \mathrm{ha})$} & $0-0.10 \mathrm{~kg} / \mathrm{ha}$ & Low & 20.0 & 0.0 & 0.0 & 20.0 & 20.0 \\
\hline & $0.10-0.20 \mathrm{~kg} / \mathrm{ha}$ & Moderate & 80.0 & 60.0 & 100.0 & 40.0 & 40.0 \\
\hline & $>0.20 \mathrm{~kg} / \mathrm{ha}$ & High & 0.0 & 40.0 & 00.0 & 40.0 & 40.0 \\
\hline \multirow[t]{3}{*}{ Organic matter (\%) } & $<1.7 \%$ & Low & 20.0 & 40.0 & 40.0 & 20.0 & 20.0 \\
\hline & $1.7-2.6 \%$ & Moderate & 60.0 & 20.0 & 40.0 & 40.0 & 40.0 \\
\hline & $>2.6 \%$ & High & 20.0 & 40.0 & 20.0 & 40.0 & 40.0 \\
\hline \multirow[t]{3}{*}{ CEC $(\mathrm{cmol} / \mathrm{kg})$} & $<6.0 \mathrm{cmol} / \mathrm{kg}$ & Very low & 40.0 & 80.0 & 100.0 & 40.0 & 60.0 \\
\hline & $6.0-12 \mathrm{cmol} / \mathrm{kg}$ & Low & 60.0 & 20.0 & 0.0 & 60.0 & 40.0 \\
\hline & $>12-25 \mathrm{cmol} / \mathrm{kg}$ & High & 0.0 & 0.0 & 0.0 & 0.0 & 0.0 \\
\hline \multirow[t]{3}{*}{ Phosphorus (mg kg-1) } & $<8 \mathrm{mg} \mathrm{kg}^{-1}$ & Low & 60.0 & 60.0 & 40.0 & 0.0 & 80.0 \\
\hline & $8-20 \mathrm{mg} \mathrm{kg}^{-1}$ & Moderate & 20.0 & 40.0 & 40.0 & 60.0 & 20.0 \\
\hline & $>20 \mathrm{mg} \mathrm{kg}^{-1}$ & High & 20.0 & 00.0 & 20.0 & 40.0 & 0.0 \\
\hline \multirow[t]{2}{*}{$\mathrm{Fe}(\mathrm{mg} / \mathrm{kg})$} & $20-1000 \mathrm{mg} / \mathrm{kg}$ & Normal & 40.0 & 80.0 & 40.0 & 80.0 & 60.0 \\
\hline & $2000 \&$ above $\mathrm{mg} / \mathrm{kg}$ & Toxicity & 60.0 & 20.0 & 60.0 & 20.0 & 40.0 \\
\hline \multirow[t]{2}{*}{$\mathrm{Cu}(\mathrm{mg} / \mathrm{kg})$} & $10-25 \mathrm{mg} / \mathrm{kg}$ & Normal & 100.0 & 100.0 & 100.0 & 100.0 & 80.0 \\
\hline & $25 \&$ above $\mathrm{mg} / \mathrm{kg}$ & Toxicity & 0.0 & 0.0 & 0.0 & 0.0 & 20.0 \\
\hline \multirow[t]{2}{*}{$\mathrm{Zn}(\mathrm{mg} / \mathrm{kg})$} & $10-120 \mathrm{mg} / \mathrm{kg}$ & Normal & 80.0 & 60.0 & 40.0 & 60.0 & 80.0 \\
\hline & $120 \&$ above $\mathrm{mg} / \mathrm{kg}$ & Toxicity & 20.0 & 40.0 & 60.0 & 40.0 & 20.0 \\
\hline \multirow[t]{2}{*}{ Mn (mgkg) } & $90-200 \mathrm{mg} / \mathrm{kg}$ & Normal & 80.0 & 100.0 & 100.0 & 60.0 & 40.0 \\
\hline & 200 \& above $\mathrm{mg} / \mathrm{kg}$ & Toxicity & 20.0 & 0.0 & 0.0 & 40.0 & 60.0 \\
\hline
\end{tabular}

Source: Computed from Field Survey Data, 2017, *Source of Threshold Values: Adapted from Havlin et al. (1999); FMANR, (1990), Smith and Doran (1996); USDA-NRCS (2011)

Similarly, The contents of available phosphorus shows that $48 \%$ of soils under intermittent short fallow, minimum tillage/mulching, mixed cropping and surface irrigation practices have low $\left(<8 \mathrm{mg} / \mathrm{kg}^{-1}\right)$ phosphorus, whereas, $52 \%$ of the farmlands in all the five farmland management practices have moderate (8.0-20.0 $\left.\mathrm{mg} / \mathrm{kg}^{-1}\right)$ phosphorus content. On average, the content of available phosphorus is neither low nor high but rather moderate under the different management practices (8.0-20.0 $\left.\mathrm{mgkg}^{-1}\right)$. By implication, it is insufficient to support active plant growth. FMANR (1990); Landon (1991); Defoer et al. (2000), cited in Essoka and Essoka (2014), concluded in their studies that the soils were deficient in available phosphorus because the values were generally less than $6.0 \mathrm{mg} / \mathrm{kg}-1$ though moderately fertile. The low levels of available $P$ in some farmlands confirm the inherent low P fertility status of the soil as confirmed by Eroarome (2005) that the soils in the Savanna grassland 
are generally low in organic matter, total nitrogen, and available phosphorus.

It is worthy of note that, micronutrient is essential for maintaining the productivity of soils and according to Rangel-Peraza et al. (2017), continuous application of inorganic fertilizer to crops without the inclusion of micronutrients can cause soils deficient in these nutrients. The contents of soil micronutrient show that the toxicity of $\mathrm{Fe}$ is exhibited in the mixed cropping system and intermittent short fallow. In contrast, mixed cropping is only toxic to $\mathrm{Zn}$, and the surface irrigation system is toxic to $\mathrm{Mn}$. Therefore, the soil in these study area is not toxic to most micronutrient by implication can support the growth of maize, millet guinea corn and ginger. Like other trace elements, $\mathrm{Cu}$ is toxic to plants if it exists in high concentrations (FAO, 1998).The content of the soil micro biomass $C$ (MBC); $\mathrm{N}(\mathrm{MBN})$ and basal respiration $\left(\mathrm{CO}_{2}\right)$ presented in Table 3 shows that the content of MBC differed significantly among the different land management practices. Sixty-four (64\%) per cent of all the farmland management practices have low MBC contents, while 36\% of farmlands have high MBC. In agricultural practices, a soil with a high test value will require little or no addition of nutrients compared with one with a low test value. The MBC contents of the soil need additional nutrients. MBC is influenced by management practices such as tillage intensity, crop type (annuals versus perennials) and crop residue management strategies (Karlen et al. 2008). The contents of microbial N (MBN) shows that $72 \%$ of all farmlands surveyed under the five farmland management practices had high MBN contents. The implication of these is that the high amount of microbial biomass will be beneficial to soil fertility and quality because the microbial biomass reflects the total organic matter content and represents its active part.

On the other hand, the best indicator of the whole metabolic activity of soil microbial populations is soil respiration, which gives room for easy comparisons of soils and reflects soil management changes (Solaiman 2007). He stressed that values higher than 2.0 metabolic quotient $\left(\mathrm{qCO}_{2}\right)$ indicate an energetically but less active microbial community. However, the result of soil basal respiration shows that the soil basal respiration is higher in all the five land management practices with the figures not less than $60 \%$, indicating that the soil basal respiration is within the threshold value consider normal for plant growth. It is only in surface irrigation practices that a proportion of the soil exhibited low basal respiration. It may be due to the use of organic manure on farms with high microbiological content. It implies then that there is much microbial community in the soils and by implication will 
affect the metabolic activity of the soil and

enhance rapid organic decomposition,

Table 3: Summary of the Key Soil Microbiological Indicators Compared with their Critical Limits (Threshold Values)

\begin{tabular}{|c|c|c|c|c|c|c|c|}
\hline \multirow{2}{*}{$\begin{array}{l}\text { Indicato } \\
\text { rs }\end{array}$} & \multirow{2}{*}{$\begin{array}{l}\text { Threshold } \\
\text { Value* }\end{array}$} & \multirow[t]{2}{*}{ Rating } & \multicolumn{4}{|c|}{ Soil Field Percentage } & \multirow[b]{2}{*}{$\begin{array}{l}\text { Surface } \\
\text { Irrigation }\end{array}$} \\
\hline & & & $\begin{array}{l}\text { Inter } \\
\text { Short }\end{array}$ & $\begin{array}{l}\text { Minimum } \\
\text { ill/Mulch }\end{array}$ & $\begin{array}{l}\text { Mixed } \\
\text { cropping }\end{array}$ & $\begin{array}{l}\text { Organic } \\
\text { Farming }\end{array}$ & \\
\hline \multirow[t]{2}{*}{ MBC \% } & $0-1.0 \%$ & low & 80.0 & 60.0 & 60.0 & 80.0 & 40.0 \\
\hline & $>1.1 \%$ & high & 20.0 & 40.0 & 40.0 & 20.0 & 60.0 \\
\hline \multirow[t]{2}{*}{ MBN\% } & $0-1.0 \%$ & Low & 20.0 & 60.0 & 20.0 & 40.0 & 0.0 \\
\hline & $>1.1 \%$ & High & 80.0 & 40.0 & 80.0 & 60.0 & 100.0 \\
\hline $\mathrm{CO}_{2} \%$ & $\begin{array}{l}1.0-2.0 \% \\
>2.0 \%\end{array}$ & $\begin{array}{l}\text { Low } \\
\text { High }\end{array}$ & $\begin{array}{l}0.0 \\
100.0\end{array}$ & $\begin{array}{l}0.0 \\
100.0\end{array}$ & $\begin{array}{l}0.0 \\
100.0\end{array}$ & $\begin{array}{l}0.0 \\
100.0\end{array}$ & $\begin{array}{l}40.0 \\
60.0\end{array}$ \\
\hline
\end{tabular}

Source: Computed from Field Survey Data, 2017, *Source of Threshold Values: Adapted from Desavathu et al. (2018); Havlin et al. (1999); FMANR (1990)

\section{Conclusion}

The textural class of the soils was sandy loam to loamy soil in nature considered suitable for the cultivation of both maize, millet, guinea corn and ginger among other crops because the percentage of sand separate was more virtually in most of the soil samples. Bulk densities, available water holding capacity, Electrical conductivity, total nitrogen, organic matter and micronutrients, micro biomass $\mathrm{N}$ and soil basal respiration were within acceptable and favourable threshold limits considered ideal and suitable for the cultivation and sustenance of plant growth at least in all of the different land management practices. While $\mathrm{pH}$ exhibit normality, Cation exchangeable capacity, phosphorus and micro biomass Carbon have low nutrient contents considered not favourable and deficient for maize, millet guinea corn and ginger. Management practices of minimum tillage/mulching, organic farming and mixed cropping are appropriate for the cultivation of the crops mentioned above because soils of these fields have higher fertility than soils from intermittent fallow and surface irrigation practices. The study recommends that for adequate fertility status in the soils from the different practices, notably intermittent short fallow, organic farming, minimum tillage/mulching and surface irrigation practice should be sustained by the complementary use of inorganic fertilizer alongside organic compost, animal dung and crop residue incorporation to enhance organic matter, Cation exchange capacity, phosphorus and micro biomass Carbon, thereby improving soil condition and retention of nutrients and water resources. Besides, liming to improve the $\mathrm{pH}$ condition to reduce strongly acidic reactions_in some fields under irrigation and organic farming management practices, 
cereals/legumes_rotation are also required on farmlands that were studied.

\section{Acknowledgement}

The authors wish to thank the Soil Laboratory Department of the Institute for Agricultural Research, Ahmadu Bello University, Zaria, Nigeria for providing the necessary facilities for the laboratory analysis.

Conflict of Interest: The authors declare that there are no conflicts of interest regarding the publication of this paper.

\section{References}

Abaje I B, Ati O F, Ishaya S (2009) Nature of Potable Water Supply and Demand in Jema'a Local Government Area of Kaduna State, Nigeria. Resource Journal of Environmental Earth Science, 1(1): 16-21. https://www.researchgate.net/publication/4 9593845_An_Analysis_of_Rainfall_Trends_in_ Kafa Retrieved on 14/06/2018

Abaje I B, Ishaya S, Usman, S U (2010) An Analysis of Rainfall Trends in Kafanchan, Kaduna State, Nigeria. Research Journal of Environmental and Earth Sciences, 2(2): 8996.https://www.researchgate.net/publication/ 49593845_An_Analysis_of_Rainfall_Trends_inKa fa Retrieved on 14/06/2018
Abaje I B, Sawa B A, Iguisi E O, Ibrahim A A (2015) Assessment of Rural Communities' Adaptive Capacity to Climate Change in Kaduna State, Nigeria. Journal of Environment and Earth Science, 5(20): 14-23. http://www.iiste.org/Journals/index.php/JE ES/article/view/26534 Retrieved on $14 / 06 / 2018$

Blake G R, Hartge K H (1986) Bulk density. in Klute A, (ed.) Methods of soil analysis, part 1, physical and mineralogical methods (2nd edition), American Society of Agronomy, Agronomy Monographs 9(1) Madison, Wisconsin

Bouyoucos G J (1962) Hydrometer Method Improved for Making Particle Size Analyses of Soils. American Society of Agronomy, 54(5): 464-465.

https://doi.org/10.2134/agronj1962.0002 1962005400050028x Retrieved on $13 / 04 / 2018$

Brady N C, Weil R R (2002) The Nature and Properties of Soils. 13th Edition. Pearson Education, Singapore.

Bremner J M, Mulvaney C S (1982) NitrogenTotal. in Page, A.L. (Ed.) Methods of Soil Analysis. Part 2. Chemical and Microbiological Properties, American Society of Agronomy, Soil Science Society of America, 595-624. 
Chapman D (1965) Methods for Measuring Cation Exchange Capacity. Cooperative Bulletin No. 493. Pp.79-86.

https://s3.amazonaws.com/udextension/law ngarden/files/2012/10/CHAP9.pdf Retrieved on $23 / 04 / 2018$

Defoer T, Budelman A (2000) Managing soil fertility in the tropics. A resource guide for participatory learning and action research. Defoer T, Budelman A (Eds.) Royal Tropical Institute, Amsterdam, The Netherlands / International Institute for Environment and Development, London, U.K.

Desavathu R N, Nadipena R A,

Peddada R J (2018) Assessment of Soil

Fertility Status in Paderu Mandal, Visakhapatnam district of Andhra

Pradesh through Geospatial techniques.

Egyptian Journal of Remote Sensing and

Space Science, 21: 73-81.

https://doi.org/10.1016/j.ejrs.2017.01.006

Retrieved on 07/09/2019

Eroarome M A (2009) Country Pasture/Forage Resource Profile Nigeria. https://www.scribd.com/document/3464401 60/FAO-Forage-Profile-Nigeria

Retrieved on 20/09/2019

Ersado L, Amacher G S, Alwang J R (2003). Productivity And Land Enhancing
Technologies In Northern Ethiopia: Health, Public Investments, And Sequential Adoption, 2003 Annual Meeting, August 1622, 2003, Durban, South Africa 25908, International Association of Agricultural Economists.

https://ideas.repec.org/p/ags/aaea03/22223.html

Retrieved on 08/09/2019 DOI: 10.22004/ag.econ.22223

Essoka P A, Essoka A. N (2014) Characterization and Classification of Obudu Mountains Steep Hillside Soils. Nigerian Journal of Soil Science, 24(1):1-12. http://soilsnigeria.net/wpcontent/Nigerian \%20Journal\%20Soil\%20Science Retrieved on $23 / 07 / 2019$

Ezekiel A A, Olarinde L O, Ojedokun, K I, Adeleke O A, Laudia T, Ogunniyi L T (2012) Effect of Irrigation and Drought on Agricultural Productivity in Kwara State, Nigeria. International Journal of the Bioflux Society, 4(1):6-9.

https://www.academia.edu/26569945/Effec t_of_irrigation_and_drought_on_agricultural Retrieved on $23 / 07 / 2019$

FAO (1998) TRACE Elements in Soils and Agriculture. FAO Soils bulletin 17.

http://www.fao.org/soilsportal/resources/soil s-bulletins/en/ Retrieved 14/03/2018 
FMANR (1990) Soil Rating Standard for Soil Fertility. Federal Ministry of Agriculture and Natural Resources, Abuja, Nigeria.

Geissien V, Sarchez-Harnandez R, Kampicher C, Ramos-Reyes P, Sepulvada-Lozado A., Ochoa-Goana S, Harnandez-Dauma S (2009) Effects of Land use Changes on Some Property of Tropical Soils. An example from South- east Mexico. Geoderma, 151: 87 -89.

http://www.christiankampichler.net/Geissen _et_al_2009.pdf Retrieved on 13/03/2018

Havlin J L, Beaton J D, Tisdale S L, Nelson W L (1999) Soil Fertility and Fertilizers. Prentice Hall, New Jersely. 345-355.

Holland M DG, Barton A D, Morph S T (1989) Land evaluation agriculture recommendation of Cross River State national park. Oban Division, prepared by Odwki, in collaboration with INNF

Johnson B, Christensen L (2004)

Educational Research: Quantitative, Qualitative, and Mixed Approaches (2 ${ }^{\text {nd }}$ ed.)

Boston, MA: Pearson Education, Inc.

Karlen D L, Andrews S S, Wienhold

B J, Zobeck T M (2008). Soil Quality

Assessment: Past, Present and Future.

Electronic Journal of Integrative

Biosciences 6(1): 3-14.
Kay B D, Angers D A (1999) Soil Structure. In Sumner M.E. (ed.) Handbook of Soil Science. CRC Press, Boca Raton, USA, 229-276

Klute A (1965) Laboratory measurement of hydraulic conductivity of saturated soil. in Black C A (ed) Methods of Soil Analysis. Part IPhysical and Mineralogical Properties, Including Statistics of Measurement and Sampling 9.1 Agronomy Monograph. The American Society of Agronomy (ASA) and Academic Press

Lal R (2015) Restoring Soil Quality to Mitigate Soil Degradation. Sustainability, MDPI, Open Access Journal 7(5):1-21

https://www.mdpi.com/20711050/7/5/587

5/pdf Retrieved on 20/11/2019

Landon J R (1991) Booker tropical soil manual: A Handbook for Soil Survey and Agricultural Land Evaluation in the Tropics .. Longman Scientific and Technical, Essex, New York.

Lindsay W L, Norvell W A (1978).

Development of a DTPA Soil Test for Zinc, Iron, Manganese, and Copper. Soil Science Society Ambassador Journal, 42: 421-428.

Liu X, Herbert S J, Hashemi A M, Zhang X, Ding G (2006) Effects of Agricultural Management on Soil Organic Matter and Carbon 
Transformation. A review. Plant Soil Environment, 52(12): 1-13.

https://www.agriculturejournals.cz/publicFil es/50927.pdf Retrieved on 16/08/2018

Menale K, Precious Z, John P, Gunnar K (2009) Sustainable Agricultural Practices and Agricultural Productivity in Ethiopia: Does Agroecology Matter? Environment for Development Discussion Paper Series April, 2009. EfD DP 09-12.

http://www.rff.org/files/sharepoint/WorkI mages/Download/EfD-DP-09-12.pdf

Retrieved on 23/01/2019

Ministry of Land and Survey (2017) Map of the Northern Guinea Savanna Agro-ecological Zones of Kaduna State

Oertli J J (2008) Soil Fertility. In Encyclopedia of Soil Science. Edited by Ward Chesworth University of Guelph Canada. Pp. 656. https://link.springer.com/978-1-4020-3995-

9 Retrieved on 12/11/2018

Oriola E O (2009) Breaking the Vicious Cycle in Irrigation Farming System for Sustainable Food Security in Nigeria. African Research Review. An International Multi-Disciplinary Journal, 3(1): 234-245.

Olsen S R, Cole C V, Watanabe F S, Dean L A (1954) Estimation of Available Phosphorus in
Soils by Extraction with Sodium Bicarbonate. USDA. Circ no. 939. U.S. Departmnt of Agriculture, Washinton, D. C

Rangel-Peraza G J, Padilla-Gasca E, Rosalía López-Corrales R, Rochín Medina J, Yaneth B, Leonel E A, Abraham E R, Tomás $O$ (2017) Robust Soil Quality Index for Tropical Soils Influenced by Agricultural Activities. https://file.scirp.org/pdf/JACEN_201711171 6252693.pdf Retrieved 05/03/2018

Richard D B, David F G, Phillip S, Robert J A, David E A (1999) Soil Sampling, Preparation, Archiving, and Quality Control. in Robertson D C, Coleman C. S, Bledsoe P S, (Eds) Standard Soil Methods for Long-term Ecological Research :3-28). Oxford University Press, New York.

https://www.cedarcreek.umn.edu/bib/10/fu ll text/ Retrieved on 04/07/2018

Shaver T M, Peterson G A, Ahuja L R, Westfall D G, Sherrod L A, Dunn G (2002) Surface Soil Physical Properties after Twelve Years of Dryland no Till Management. Soil Science Society Ambassador Journal, 66(4):12961303.

https://doi.org/10.2136/sssaj2002.1296

Smith J L, Doran J W (1996) Measurements and use of $\mathrm{pH}$ and Electrical Conductivity for Soil Quality Analysis In: Methods for Assessing 
Soil Quality, SSSA Special Publication 49. SSSA, Madison, pp 169-185

Solaiman Z (2007) Measurement of Microbial Biomass and Activity in Soil. Soil Biology, Vol. 11 Advanced Techniques in Soil Microbiology Varma A R Oelmüller (Eds.) Springer-Verlag Berlin Heidelberg.

https://www.researchgate.net/publication/2 26626355 Retrieved 05/03/2018

Terr Africa Partnership (2006) Regional Sustainable land Management [Brochure]. Washington DC, USA.

USDA Natural Resource Center Services (2011) Soil quality Indicators- Soil pH physical Indicator Sheet. https://www.nrcs.usda.gov/Internet/FSE_DO CUMENTS/nrcs142p2_053293.pdf Retrieved on $12 / 11 / 2018$

Van Reeuwijk L P (2002). Procedures for Soil Analysis. International Soil Reference and Information Centre. Technical Paper. Food and Agriculture Organisation of the United Nation.
https://www.isric.org/sites/default/files/ISR IC_TechPap09.pdf Retrieved on 20/11/2019

Vance E D, Brookes P C, Jenkinson D S (1987) An Extraction Method for Measuring Soil Microbial Biomass Carbon, Soil Biology and Biochemistry, 19: 703-707.

Worlf P (1995) The problem of sustainability of irrigation system. Applied Geography 45/46:55-62

Woodfine A (2009) Using Sustainable Land Management Practices to Adapt to and Mitigate Climate Change in Sub-Saharan African. Resource guide version 1, Terr Africa Regional Sustainable Land Management. http://www.ipcinfo.org/fileadmin/user_uplo ad/terrafrica/docs/SLM_SUB-AFRICA.pdf http://www.terrafrica.org Retrieved on $20 / 11 / 2019$

Yakubu S (2010) Changes in Soil Physical Properties due to Different land Uses in Part of Nigerian Northern Guinea Savanna. The Zaria Geographer Journal, 18(1): 47-56 